\title{
VILLAGE VS TECHNOLOGY: CRITICAL DISCOURSE ANALYSIS OF TECHNOLOGY-BASED VILLAGES GOVERNMENT SYSTEM IN BENGKALIS REGENCY, RIAU PROVINCE
}

\author{
By: Rijalul Fikri \\ Email: rijalul.fikri@soc.uir.ac.id
}

\begin{abstract}
The development of technology and information facilitates make human activities easier and more efficient. Included in the management of government organizations, started a lot of application of technology. The Government of Indonesia, through the Ministry of Administrative and Bureaucratic Reform and the Ministry of Communication and Information, has formed a team to accelerate the implementation of the Electronic-Based Government System not only at the level of the national government until the village government. The main target is the empowerment of the village government through a technology-based village government system. By making an application for the village government system, which includes e Budget Base ePerformance (ePlanning, eBudgeting, eProcurement, eMoney, eAudit). One of the areas that are intensely doing this, is the Bengkalis Regency Government, through the implementation of the Broadband Village program from the Ministry of Communication and Information. So now, almost all villages in Bengkalis Regency already have village websites. The interesting question is does the village have to understand technology? Does the village have to implement a technology-based government system? Does the state forget that the village and its community have a Self Governing Community?. which is long before the electronic village-based government system exists and develops. This will be answered by using discourse analysis. Because discourse believes that power relations in society influence and shape ways, how knowledge is created. The discourse in this paper is the implementation of a Technology-Based Government System, which is believed to be a tool that forms power relations in society through processes of defining, isolating, justifying. This paper then tries to express the state power represented in its efforts to implement a technology-based village government system.
\end{abstract}

Keyword : technology-based village government system 
Proceeding ICOGISS 2019

Page 445-454 ISBN: 978-602-6 988-75-1

Web Jurnal Online: jurnal.unmuhjember.ac.id

By: Rijalul Fikri

Village Vs Technology: Critical Discourse Analysis Of Technology-Based Villages

Government System In Bengkalis Regency, Riau Province

\section{INTRODUCTION}

Now globalization demands the realization of efficiency and effectiveness in the whole world. The progress of technology communication and transportation has made the mobility of people, objects, and information can be done quickly, precisely and accurately and could reach areas widely and without limits. fact, there has been a technological convergence between computer technology, electronics, telecommunications, and broadcasting, which seems to know no national geographical boundaries. And now, the world is in the midst of a transition to the industrial revolution 4.0 era. or the fourth world industrial revolution, where technology has become the basis of human life. Everything becomes limitless and is not limited to the development of the internet and digital technology. This era affects many aspects of life both in the fields of economics, politics, culture, art and even to the world of education. To deal with world developments that have entered the industrial revolution era 4.0 Indonesia needs an initiative towards this by utilizing the development of the internet and technology, one of which is the discourse on the application of an Electronic-Based Government System (SPBE). the not only government in a wide range of areas such as provincial and district/city governments but the application of SPBE also touched the realm of village governance. to develop the potential of the village through the use of information and communication technology, Indonesia through the Ministry of Communication and Information inaugurated the Integrated Broadband Village Development Program in several priority districts/cities (LOKPRI) based on Regulation of the Head of National Border Management Agency No. 1 2015. Integrated broadband villages are villages that will be equipped with network facilities or internet access, end-user devices and applications that match the characteristics of the local population.

The Integrated Broadband Village Development Program is a program that will later support the implementation of SPBE. Where the Village Information System is an integral part of the implementation of the Village Law. In the Third Section of Law Number 6 of 2014 concerning Villages Article 86 concerning the Rural Development Information System and Rural Area Development it is clearly stated that the village has the right to obtain access to information through an information system developed by the Regency or City Government. Through the discourse on the Village Information Technology System in its development, it is not only a tool to monitor development, but also as a village library containing data for planning village development, and rural areas, of course. In its development, the village provides broad opportunities to develop village potential by utilizing this information technology. In Indonesia, many villages have used this information technology to realize the SPBE. How much information technology is applied in the village?. First, what many villages do in the use of information technology by creating official village websites using the desa.id domain. Regarding the official website of this village, the benefits are to provide information to the community regarding the activities and potential of the village. Second, the use of village technology is also done by creating a system or application that is useful as a database that contains population data, territory, potential and other data that the village has. Third, besides the database of village information technology governance, it also supports the use of 
Proceeding ICOGISS 2019

Page 445-454 ISBN: 978-602-6 988-75-1

Web Jurnal Online: jurnal.unmuhjember.ac.id

By: Rijalul Fikri

Village Vs Technology: Critical Discourse Analysis Of Technology-Based Villages

Government System In Bengkalis Regency, Riau Province

electronic government that is useful for transforming conventional supportive governance into online.

However, the village still has major limitations in the use of information technology to realize this SPBE. The main limitation lies in independent information technology resources. Many villages use third parties to help villages to realize this SPBE. In this paper, the author tries to look at the two major providers of village information system creation services, namely Open Village Information Systems (OPENSID) and SIDEKA. From number of village information system service providers, data is obtained about the number of villages in Indonesia that have utilized information technology in their governance, shown in the following figure:

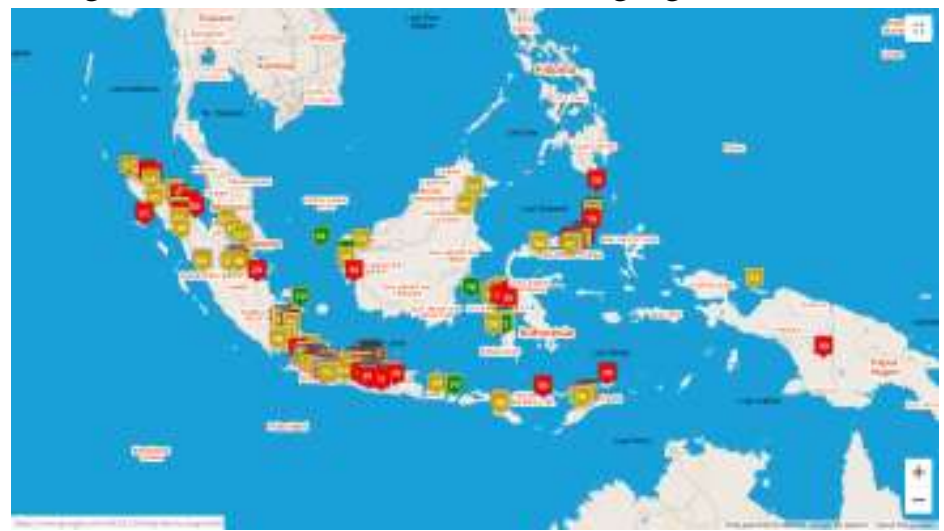

Picture 1. SIDEKA System User Distribution in Indonesia

In the official SIDEKA website, users of this village governance platform have reached 6536 villages spread throughout Indonesia. Whereas for OPENSID users it has reached a total of 6092 villages, with the distribution of 3513 villages and villages online using 4175 villages offline. From these data it can be described that in the utilization of village information systems more than 12,000 villages have been utilized out of a total of 74,957 villages in Indonesia.

It is interesting when talking about the context of village governance comprehensively. wherein the implementation of the village government system in Indonesia, there are still many villages which in the implementation of their government try to maintain the existence of the village as an area that has genuine autonomy which is a form of uniqueness from the village. On the other hand, the state also recognizes the existence of this village as an entity that is not separated from the Unitary State of the Republic of Indonesia. Like villages in Bengkalis Regency, Riau Province. In Bengkalis Regency there are still villages with local wisdom that have a strong social life to certain tribes. As in Pinggir Sub-District which has 15 villages with a majority of the indigenous Sakai tribes. The Sakai tribe itself has a culture that tends to avoid the moderate sphere in its life. On the banks of the Bengkalis regency precisely on the island of Rupat, 9 villages also have local wisdom that is known to be to be strong with traditional life. They are known as "native tribes/tribes of akits" who became the majority of the people in these villages 
Proceeding ICOGISS 2019

Page 445-454 ISBN: 978-602-6 988-75-1

Web Jurnal Online: jurnal.unmuhjember.ac.id

By: Rijalul Fikri

Village Vs Technology: Critical Discourse Analysis Of Technology-Based Villages

Government System In Bengkalis Regency, Riau Province

As a principle of traditional society, of course, the use of technological systems in governance and society is something foreign to them. the state with "power" that it has also sought to implement the village based on this technology. Political perspective, the state's efforts in implementing SPBE can be seen as a discourse on "the power of knowledge" that is trying to be developed in the village government. While there are still many villages that have a self- governing community as a characteristic of the village. Therefore, this paper tries to answer the basic questions related to the discourse of implementing this technology-based government system. First, how is the discourse on the application of this technology-based village government system? Second, how do the self-governing communities that the village have as marginalized discourse? To answer this question, this paper tries to express it using Critical Discourse Analysis by using the conception of the discourse of knowledge described by the Foucoult.

\section{METHOD}

The discourse on the application of a technology-based village government system in Bengkalis Regency is seen as the state's construction of knowledge that must be understood by the community, in case the village government. In this paper to look at the discourse on the application of a technology-based village government system in Bengkalis District, critical discourse analysis that uses elaboration Foucaultian discourse analysis adopted by Eriyanto is used. ${ }^{1}$ In Foucault's view, discourse causes a narrowing of one's area of concept, to eliminate the wide range of phenomena that are determined as real or valuable, and then build a set of discursive practices. ${ }^{2}$ The statement underlines the tendency for discourse domination to be present in sociocultural. There are two kinds of consequences of the dominant discourse. ${ }^{3}$ First, dominant discourse provides direction on how an object must be read and understood, so that the extent to which the object must be defined and will form a discursive pattern. Second, the discursive structure of an object does not mean truth. The power to choose and support discourse makes certain discourses dominant, whereas other discourses will be marginalized or submerged ${ }^{4}$. For Foucault, discourse is controlled, selected and managed. So that by using Foucault's perspective, he can dissect the concept of power in the application of technology-based village government systems in Bengkalis Regency, Riau Province. There are several stages in analyzing discourse using Foucault's perspective. First, to find out how the power of knowledge of "technology-based village government systems" was built, it is necessary to know how the dissipated structure of the power of knowledge is formed, this is done by mapping existing dissipating structures by analyzing them as dominant discourses.

Second, after understanding how the power of knowledge of the technologybased village government system as a dominant discourse is formed, it is then necessary to know the marginalized discourse which is a form of interpretation of the dominant discourse structure that is formed.

\footnotetext{
${ }^{1}$ Eriyanto. 2001. Analisis Wacana: Pengantar Analisis Teks Media. Yogyakarta: LkiS. Hal. 65.

${ }^{2}$ Ibid. Hal. 51.

${ }^{3}$ Ibid. Hal. 77

${ }^{4}$ Aditjondro, 1994. Dalam Eriyanto Op. Cit. Hal. 77
} 
Proceeding ICOGISS 2019

Page 445-454 ISBN: 978-602-6 988-75-1

Web Jurnal Online: jurnal.unmuhjember.ac.id

By: Rijalul Fikri

Village Vs Technology: Critical Discourse Analysis Of Technology-Based Villages

Government System In Bengkalis Regency, Riau Province

\section{Framework}

In understanding knowledge as a power we need to understand Michel Foucault's view which is quite relevant to discuss power-knowledge. according to him, knowledge has been institutionalized as power. Knowledge has the power to force someone to say certain things, in his study of insanity, for example, Foucault seeks to capture the disposition of knowledge on the meaning of normality as opposed to abnormality or madness. ${ }^{5}$

Stabilization of knowledge so that it becomes distinctive involves the ongoing operation of power which is inseparable from how scientific knowledge relates to lay knowledge. Consolidation takes place at the level of discourse. As an episteme, relation to scientific knowledge no longer stands as a way of looking at the distinction and separation between the right from the wrong, but the separation in the practical domain between what might be impossible or thought out by the basis of scientific knowledge. Through episteme, the strategy for operating power in knowledge can be known. ${ }^{6}$

In the Foucault concept, discourse contains an understanding of the power behind these statements. This notion believes that power relations in people influence and shapes how we communicate with each other and how knowledge is created. Discourse is believed to be a tool that forms power relations in society through processes of defining, isolating, justifying. Power in discourse determines what can be said, which is not for a particular field, at a certain period time. The following is illustrated how the framework in this paper:

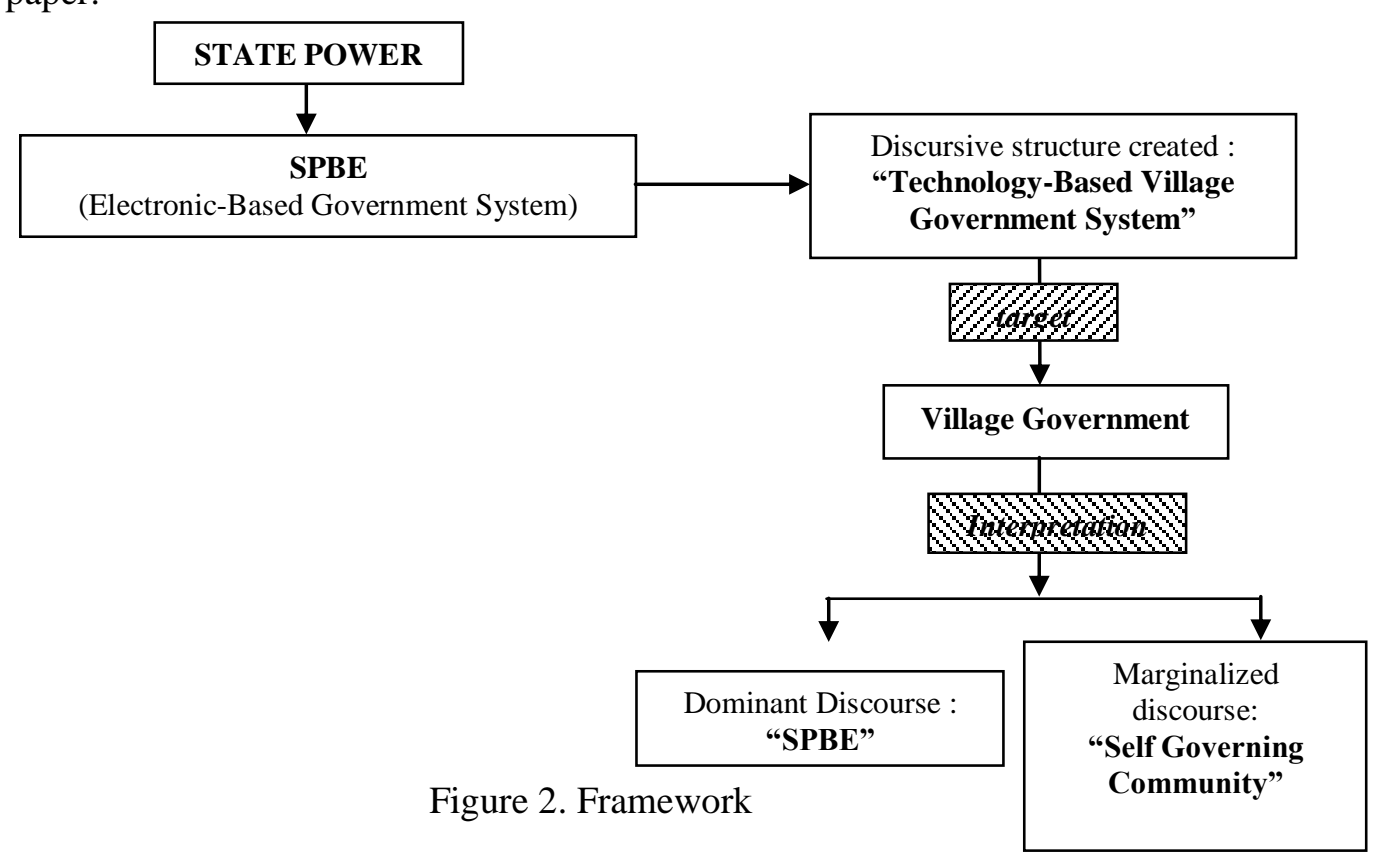

\footnotetext{
${ }^{5}$ Foucault, 1978. The History of Sexuality: An Introduction, Vol. I, Penguin, Harmondsworth (first published 1972).

${ }^{6}$ Dalam Abdil Mughis, 2013. Teori Kekuasaan Michel Foucault: Tantangan Bagi Sosiologi Politik. Jakarta. Masyarakat: Jurnal Sosiologi
} 
Proceeding ICOGISS 2019

Page 445-454 ISBN: 978-602-6 988-75-1

Web Jurnal Online: jurnal.unmuhjember.ac.id

By: Rijalul Fikri

Village Vs Technology: Critical Discourse Analysis Of Technology-Based Villages

Government System In Bengkalis Regency, Riau Province

\section{RESULT}

The electronic-based government system (SPBE) is a policy made by the state as a form of adjustment to globalization and demands for changing times. So the government thinks to make a policy that can be implemented effectively at all levels of government. The village government is inseparable from the efforts of the state to try to construct related knowledge as a system of village governance based on this technology. Several things are done in constructing a discourse on a technology-based government system in the village government.

First, the existence of the state as the owner of power, so that the state could construct knowledge that can be disseminated to the community as a truth that must be done. In the discourse of the SPBE of the country through the village government, the existence of the village information technology is a singularity and security of a village. The government through the Ministry of Communication and Information provides DesTIKa desa.id awards to villages that can use information and communication technology to speak out.

Second, the state also encourages the existence of a technology-based government system as a manifestation of ease in implementing governance including in the village. The convenience obtained in this technology-based government system is a basis for strengthening the position of the SPBE as knowledge must be trusted and implemented by the village government.

Third, the existence of service providers who can provide village information needs comprehensively is also a strong basis for how the SPBE discourse can provide fresh winds in the problems of village governance in Indonesia. In the following section, we will explain how SPBE is the dominant discourse in technology implementation in village government

\section{a. Technology-Based Village Government Systems as Dominant Discourse}

The implementation of a technology-based village government system as a discourse can be seen from how the state gives great effort to this idea. The state confirmed the discourse of the application of a technology-based government system by making it the basis of the truth that must be carried out. The state then transferred it to the Village Information System as practices that were protected and inseparable from the implementation of Law Number 6 of 2014 concerning Villages. In article 86, the third part is where the Village Development Information System and Rural Area Development explain.

- Villages have the right to access information through the Village information system developed by the Regency / City Government.

- The Government and Regional Government must develop Village information systems and the development of Rural Areas.

- The village information system as referred to in paragraph (2) includes hardware and software facilities, networks, and human resources. 
Proceeding ICOGISS 2019

Page 445-454 ISBN: 978-602-6 988-75-1

Web Jurnal Online: jurnal.unmuhjember.ac.id

By: Rijalul Fikri

Village Vs Technology: Critical Discourse Analysis Of Technology-Based Villages

Government System In Bengkalis Regency, Riau Province

- Village information system as referred to in paragraph (2) includes Village data, Village Development data, Rural Areas, and other information relating to Rural Development and Rural Area development.

- The village information system as referred to in paragraph (2) is managed by the Village Government and can be accessed by the village community and all stakeholders.

- District/City Governments provide information on district/city development planning for villages

Through this rule, the village government sees the SPBE is a necessity that they must or not have to carry out. The discourse of SPBE is constructed as a form of excellence and progress that the village government has. SPBE provided by service providers such as Open SID and SIDEKA systems have features that can facilitate village government governance, such as online population services, population databases, regional databases and financial databases that are usable and attractive features. in this discourse. In the discourse on the SPBE application, the village government in Bengkalis has also implemented SPBE at the most common level to the most specific.

In Bengkalis Regency, out of 136 villages, almost $80 \%$ of the villages have official village government websites with desa.id domains. then from most of the villages, there were several villages that used Open SID, such as Kelapapati village, Pedekik Village, and Muntai Barat Village. Whereas those using SIDEKA in Bengkalis Regency have Wonosari Village. Villages that do not have an official website in Bengkalis Regency are villages that are in the interior of Bengkalis and the coastal bengkalis, these villages are the places of residence of the tribe of Sakai and the tribe of akits or indigenous tribes.

In a system created by SIDEKA, there are several features offered such as population data management features, financial data, and poverty data. Filtering, sorting, and searching data can be done with just a few clicks. The next feature owned by SIDEKA is a feature that can serve the needs of the village community in making an optimal statement. Letters that can be easily made with Sideka include a certificate of domicile, certificate of ownership of land, certificate of incapacity, and so on.

Meanwhile, in the Open SID system, it is not much different from SIDEKA. At Open SID it contains the administration module. The Administration module contains features to facilitate village office tasks such as managing village data, printing letters and reports; and to manage the information displayed on the village website. More complete features provided by Open SID include village information features, administrative area data, family and population data, migrant population data, household data, group data, statistical data, letter printing features, analysis features, etc. The existence of this system is a big selling point for the village government. This can not be separated from the many benefits obtained in this system if the village government applies it in the implementation of its governance. 
Proceeding ICOGISS 2019

Page 445-454 ISBN: 978-602-6 988-75-1

Web Jurnal Online: jurnal.unmuhjember.ac.id

By: Rijalul Fikri

Village Vs Technology: Critical Discourse Analysis Of Technology-Based Villages

Government System In Bengkalis Regency, Riau Province

\section{b. Self Governing Community as a Marginalized Discourse}

In discussing the discourse on the application of technology-based village governance systems there are things that people often ignore. Without realizing the dominant discourse that was tried to be constructed by this state became a new knowledge in the village government which then had to be carried out. The conception of the village government as the owner of autonomy is actually often overlooked by ideas that the state tries to construct, including also in the discourse of the system of village governance based on this technology. The state considers the village government unable to take care of itself, which then needs to be given knowledge in managing its government affairs.

The consequence of the recognition of genuine autonomy is that the village has the right to regulate and manage its own household based on the origins and local customs (self-governing community), and is not the authority that is handed over by the superior government to the village. The village is a Self Community which is a selfregulating community. With the understanding that the Village has the authority to manage and regulate the interests of its community in accordance with local conditions and socio-culture, the position of the Village which has genuine autonomy is very strategic so that it requires balanced attention to the implementation of Regional Autonomy

In the village government structure in Bengkalis Regency, the people who are in the social structure are still "backward" into villages that are in the marginalized discourse. They are in a discourse that does not become a knowledge that is understood and carried out by others. The discourse that they hold is more on the effort to implement "the real auotonomy" as a manifestation of the original autonomy of the village.

Like the Sakai tribal community that inhabits 15 villages in Bengkalis Regency. The Sakai community in the past had a government system that they called Perbatinan led by the Batin. Sakai people occupy 13 tributaries, their settlements are called inner ones which are then called villages in the Republic of Indonesia government. This Perbatinan consists of Perbatinan Five and Perbatinan Eight. Referred to as Perbatinan Five of their respective perbatinan have land of customary rights and forests in (1) Minas; (2) Kuala Penaso; (3) Beringin; (4) Belutu; dan (5) Tengganau. Perbatinan Delapan adalah kelompok orang Sakai yang di beri hak untuk membuka hutan oleh Raja Siak Sri Indrapura meliputi wilayah (1) Petani; (2) Sebanga; (3) Air Jamban; (4) Pinggir; (5) Semunai; (6) Sam-Sam; (7) Kandis; (8) Balai Makam.

In addition to villages with a majority of tribes sakai, Bengkalis also has a village with the majority still maintaining its local wisdom, namely the tribe of akits or tribes of the indigenous people. They are also commonly referred to by some as a sea tribe because their lives are much related to marine life. Their activities are generally related to rivers, straits and the sea, such as fishing. In addition to catching their livelihood fish is by utilizing mangrove wood found in rivers, straits or on the seafront, namely utilizing mangrove forests. The wood is usually used as firewood, and today many are also processed into charcoal wood. The tribe of akit people also have special characteristics in carrying out their social life. The mind as a traditional leader or tribe still plays an 
Proceeding ICOGISS 2019

Page 445-454 ISBN: 978-602-6 988-75-1

Web Jurnal Online: jurnal.unmuhjember.ac.id

By: Rijalul Fikri

Village Vs Technology: Critical Discourse Analysis Of Technology-Based Villages

Government System In Bengkalis Regency, Riau Province

important role, both in socio-cultural, and traditional ceremonies. The mind as a form of informal government can also be called as a form of original autonomy owned by a village. $^{7}$

The community with this local wisdom cannot be denied. In every social life, they are based on philosophical values that have long-lived and developed amid during this community. These communities believe that the traditional life they are living in is an effort to preserve the heritage of their parents. This local wisdom is often overlooked when faced with "newness" because what is considered as what the community does as its local wisdom is something that is marginalized.

\section{CONCLUSSION}

In the discourse analysis of the application of a technology-based government system in Bengkalis Regency, we can conclude this discourse as a state construction effort towards knowledge regarding the application of technology in village governance, which is summarized in the following conclusions:

First, the discourse of technology-based village government systems is a dominant discourse, this can be seen from how the state builds and constructs this discourse as a knowledge that is strengthened in the rules that must be implemented by the village government.

Second, in the interpretation of the technology-based village governance system discourse, there is a discourse that is marginalized namely the form of original autonomy from the village itself through the self-governing community, which makes each village must have its own way and specificity in regulating its governance and social life.

${ }^{7}$ Julianus Limbeng, 2011. Suku Akit Di Pulau Rupat, Jakarta: Perpusnas 
Proceeding ICOGISS 2019

Page 445-454 ISBN: 978-602-6 988-75-1

Web Jurnal Online: jurnal.unmuhjember.ac.id

By: Rijalul Fikri

Village Vs Technology: Critical Discourse Analysis Of Technology-Based Villages

Government System In Bengkalis Regency, Riau Province

\section{References}

Abdil Mughis, 2013. Teori Kekuasaan Michel Foucault: Tantangan Bagi Sosiologi Politik. Jakarta. Masyarakat: Jurnal Sosiologi

Eriyanto. 2001. Analisis Wacana: Pengantar Analisis Teks Media. Yogyakarta: LkiS.Hal. 65.

Foucault, Michel, 1978. The History of Sexuality: An Introduction, Vol. 1. New York: Vintage Books.

2002. Power/Knowledge: Selected Interviews and Oter Writings, 1972-1977, Terjemahan Wacana Kuasa/Pengetahuan: Wawancara

Pilihan dan Tulisan-Tulisan 1972-1977. Jogjakarta, Bentang Budaya

Julianus Limbeng, 2011. Suku Akit Di Pulau Rupat, Jakarta: Perpusnas. Retrieved from repositori.kemdikbud.go.id/7746 